\title{
Sarekat Islam: Mediasi Perkecuan di Surakarta Awal Abad Ke-20
}

\author{
Siti Rahmana \\ Dosen Prodi Sejarah Peradaban Islam IAIN Bengkulu \\ siti_rahmana_2009@yahoo.com
}

\begin{abstract}
Racial sentiment is a classic problem that occurred between ethnic Chinese and indigenous peoples in the archipelago during the colonial period. This paper focuses on the problem of racial sentiment in Surakarta early 20th century. The purpose of this paper is to analyze the relevance of racial sentiments, annihilations, and organizations Sarekat Islam. This work uses research method with study technique in the form of literature study. The findings of this study that the condition of racial sentiment that increased in Surakarta early 20th century to compound the deception. Increased letters of causality led to an organization that named Sarekat Islam. The presence of the Sarekat Islam in the midst of socio-economic decline is a form of indigenous people in the face of problems with Chinese terms, as well as a defensive measure against Dutch Colonial policy.
\end{abstract}

Keywords: Racial sentiment, hoards, Surakarta, Sarekat Islam.

\begin{abstract}
Abstrak
Sentimen rasial merupakan permasalahan klasik yang terjadi antara etnis cina dan kaum pribumi di nusantara sejak masa kolonial. Tulisan ini memfokuskan diri pada permasalahan sentimen rasial di Surakarta awal abad ke-20. Adapun tujuan tulisan ini yaitu menganalisis relevansi sentimen rasial, perkecuan, dan organisasi Sarekat Islam. Karya ini menggunakan metode historis dengan teknik penelitian berupa studi pustaka. Temuan riset ini yaitu kondisi sentimen rasial yang meningkat di Surakarta awal abad ke-20 memunculkan praktik perkecuan. Meningkatnya kasus perkecuan menyebabkan munculnya sebuah organisasi yang diberi nama Sarekat Islam. Hadirnya Sarekat Islam ditengah-tengah keterpurukan sosial-ekonomi merupakan bentuk resistensi kaum pribumi dalam menghadapi persaingan dengan etnis Cina, sekaligus sebagai tindakan bertahan menghadapi kebijakan Kolonial Belanda.
\end{abstract}

Kata kunci: Sentimen rasial, perkecuan, Surakarta, Sarekat Islam.

\section{PENDAHULUAN}

Indonesia merupakan negara yang kaya akan keanekaragaman budaya. Keanekaragaman budaya tercermin dari banyaknya bahasa dan dialek yang digunakan oleh berbagai suku bangsa di Indonesia. Selain itu, terdapat juga beberapa agama dan kepercayaan yang mendominasi. Kondisi ini menjadi salah satu faktor terciptanya masyarakat majemuk. ${ }^{1}$

Di tengah kemajemukan budaya, masyarakat Indonesia ternyata masih mampu mempertahankan kebersamaan dengan bermodalkan sikap gotongroyong, tolong-menolong, dan toleransi. Pada sisi yang lain, sebuah masyarakat

${ }^{1}$ Di Indonesia ada kurang lebih 300 suku bangsa dengan bahasa dan dialek yang berbeda. Terdapat juga beberapa agama dan kepercayaan seperti Islam, Katholik, Kristen, Hindu, Budha, dan Kong Hu Cu. Lihat Srijanti dkk, Etika Berwarga Negara Edisi II : Pendidikan Kewarganegaraan untuk Perguruan Tinggi (Jakarta : Salemba Empat, 2008), hlm. 46-47. 
majemuk tentu tidak bisa lepas dari munculnya perbedaan-perbedaan. Perbedaan-perbedaan tersebut terlihat dari pola pikir, cara pandang, dan perilaku masyarakatnya. Dari perbedaan tersebut, tidak jarang memunculkan konflik suku, ras, atau agama yang berujung pada kekerasan. Sebagai contoh ; peristiwa pembantaian etnis Madura di Sampit, peperangan antara komunitas agama Islam dan Kristen di Maluku dan Poso, kerusuhan dan pemerkosaan terhadap etnis Cina di Jakarta dan Solo, pembantaian terhadap orang-orang Aceh dan Papua, serta kasus-kasus lainnya. ${ }^{2}$

Pada masa sebelum kemerdekaan, permasalahan antara etnis Cina dengan kaum pribumi sebenarnya sudah ada sejak kedatangan bangsa Eropa di Indonesia, yaitu semenjak Kolonial Belanda menjalin hubungan kerjasama dengan orang-orang Cina di Indonesia. Kondisi ini menjadi salah satu faktor munculnya sentimen rasial ${ }^{3}$, yaitu konflik antara etnis Cina dengan kaum pribumi. Tulisan ini lebih memfokuskan diri pada kondisi sentimen rasial di Surakarta awal abad ke-20. Selain itu, tulisan ini juga akan memberikan gambaran bagaimana awal berdirinya organisasi Sarekat Islam disebabkan karena kondisi sentimen rasial antara etnis Cina dengan kaum pribumi, tercermin dari munculnya fenomena sosial berupa praktek perkecuan ${ }^{4}$.

Sarekat Islam merupakan organisasi semula bernama Rekso Roemekso ${ }^{5}$ yang didirikan oleh Samanhudi. Dalam perkembangannya, Rekso Roemekso mendapat status hukum, sehingga dari sebuah organisasi ronda sederhana berubah menjadi organisasi dagang bernama Sarekat Dagang Islam (SDI). Sarekat Dagang Islam dapat merangkul masa dari berbagai lapisan termasuk kalangan buruh dan petani, sehingga keanggotaannya berkembang pesat. Selanjutnya, Sarekat Dagang Islam berubah menjadi Sarekat Islam (SI), organisasi ini tidak hanya bergerak dalam bidang perdagangan saja, melainkan juga dalam bidang politik. Hadirnya Sarekat Islam di tengah-tengah keterpurukan kondisi sosial-ekonomi kaum pribumi, mendorong lahirnya "kepentingan bersama" yang pantas hlm. 20.

2 Budi Susanto, Identitas dan Postkolonialitas di Indonesia (Yogyakarta : Kanisius, 2003),

${ }^{3}$ Sentimen rasial berinduk pada rasisme. Rasisme merupakan pandangan yang menganggap satu kelompok ras lebih unggul daripada ras lain dalam soal hak-hak dan martabat, yang kemudian mengakibatkan penjajahan dilakukan oleh ras satu terhadap ras lain. Lihat Tissa Balasuriya, Teologi Siarah (Jakarta : Gunung Mulia, 2004), hlm. 50. Rasa iri hati, cemburu, dan dengki yang menggambarkan ketidaksenangan kolektif menumbuhkan sentimen rasial. Periksa Ferdinand Suleeman, dkk (penyunting), Bergumul dalam Pengharapan (Jakarta : Gunung Mulia, 2004), hlm. 368. Sentimen rasial anti-Tionghoa mengalami pemupukan sehingga meledak berkali-kali di Indonesia baik di masa Orde Lama terlebih lagi masa Orde Baru. Tentang hal ini lihat Budi Susanto, op., cit., hlm. 68.

${ }_{4}^{4}$ Perkecuan berasal dari kata kecu. Kecu mengacu pada tindakan kriminal sekelompok orang atau kawanan orang bersenjata yang meminta dengan paksa harta korban pada malam hari dan sering diikuti dengan penyiksaan serta pembunuhan korban. Sehingga perkecuan termasuk dalam "sentimen rasial secara radikal". Lihat, Wasino, Kapitalisme Bumi Putera : Perubahan Masyarakat Mangkunegaran (Yogyakarta : LKIS, 2008), hlm. 323-324.

5Takashi Shiraishi, Zaman Bergerak : Radikalisme Rakyat di Jawa 1912-1926 (Jakarta : Pustaka Utama Grafiti, 1997), hlm. 55. 
diperjuangkan dan direbut dari tangan Kolonial Belanda. Hal inilah yang menyebabkan Sarekat Islam mampu mewadahi terciptanya semangat persatuan, melahirkan rasa nasionalisme, sekaligus alat pencari identitas kebangsaan kaum pribumi di Surakarta.

\section{HASIL DAN PEMBAHASAN}

\section{Relevansi antara Sentimen Rasial dan Awal Mula Sarekat Islam}

Etnis Tionghoa selama ratusan tahun dijadikan alat oleh Kolonial Belanda untuk menjadi mesin penghasil uang yang sangat efektif. Kondisi ini menimbulkan "kebencian" dan "sentimen rasial" dari sebagian rakyat Indonesia. ${ }^{6}$ Sentimen rasial kaum pribumi terhadap keberadaan etnis Cina di Surakarta tidak dapat dilepaskan dari peran besar Kolonial Belanda, sebagai penguasa yang membuat kebijakan dan memonopoli perdagangan. Hak-hak istimewa diberikan Kolonial Belanda kepada etnis Cina dalam kebijakan ekonomi seperti perdagangan, dan kemudian memunculkan ketimpangan sosial bagi kaum pribumi. Kondisi ini mendorong timbulnya sebuah tindakan protes, seperti pemberontakan petani di Banten tahun $1888^{7}$. Tindakan protes secara radikal dari kaum pribumi tersebut dapat diasumsikan dalam meningkatnya kasus perkecuan pada awal abad ke-20.

Meningkatnya kasus perkecuan awal abad ke-20 di Surakarta merupakan sebuah bentuk konflik antara kaum pribumi dengan etnis Cina. Konflik ini hanya salah satu bagian dari konflik antara kaum pribumi dengan etnis Cina yang terjadi sejak etnis Cina mulai memasuki wilayah-wilayah Indonesia. Adanya sentimen rasial kaum pribumi diwujudkan dalam bentuk perkecuan di Surakarta, dilatarbelakangi oleh kesenjangan status sosial yang tinggi, serta pengaruh kebijakan Kolonial Belanda yang memberikan hak istimewa kepada etnis Cina. Sehingga, masyarakat pribumi hanya mampu mengungkapkan kekecewaan terhadap keadaan dengan melakukan tindakan kriminal yaitu menjadi kecu.

Di balik konflik antara kaum pribumi dengan etnis Cina, ada pengaruh positif yang muncul, yaitu terbentuknya kelompok ronda Rekso Roemekso diprakarsai oleh para pedagang batik di Laweyan. Aktivitas kelompok ronda ini diantaranya mengatasi fenomena perkecuan yang membuat daerah Laweyan tidak aman, di tengah-tengah persaingan antara pedagang batik Cina dengan pedagang batik pribumi. Pada perkembangan selanjutnya, kelompok ronda Rekso Roemekso diarahkan menjadi organisasi sosial-ekonomi, yang diberi nama Sarekat Dagang Islam. Sarekat Dagang Islam menjadi wadah bagi para pedagang

6Benny G. Setiono, Tionghoa dalam Pusaran Politik (Jakarta : Transmedia, 2008), hlm. 293.

${ }^{7 B a c a}$ buku Sartono Kartodirdjo, Pemberontakan Petani Banten 1888 : Kondisi, Jalan Peristiwa, dan Kelanjutannya : Sebuah Studi Kasus Mengenai Gerakan Sosial di Indonesia. Penerjemah : Hasan Basri (Jakarta : Pustaka Jaya, 1984). Lihat juga tentang pemberontakan petani melawan pemerasan dalam buku Marwati Djoened Poesponegoro dan Nugroho Notosusanto, Sejarah Nasional Indonesia IV (Jakarta : Balai Pustaka, 2008), hlm.400-424. 
Islam untuk bertahan dari sikap monopoli pedagang Cina. Dengan kata lain, Sarekat Dagang Islam yang akhirnya berubah nama menjadi Sarekat Islam hadir di tengah-tengah masyarakat yang membutuhkan solusi untuk menghadapi problematika sosial saat itu.

\section{Perkecuan: Bentuk Sentimen Rasial Kaum Pribumi}

Praktek perbanditan sosial merupakan salah satu ciri penting dinamika sosialekonomi-politik pedesaan di Jawa, seperti perbanditan di Batavia dan Banten, kecu di Yogyakarta dan Surakarta, pembakaran tebu di Pasuruan dan Probolinggo, antara 1850-1942. ${ }^{8}$ Pada dasarnya yang disebut bandit adalah individu atau kelompok orang yang menyerang dan merampok dengan kekerasan. Hal ini senada dengan pengertian perbanditan menggunakan sudut pandang Neerlandosentris ${ }^{9}$. Sebaliknya, tulisan ini memberikan pengertian perbanditan berdasarkan sudut pandang Indonesiasentris ${ }^{10}$. Perbanditan adalah suatu tindakan dari individu atau kelompok orang untuk mendapatkan kembali haknya yang telah dirampas oleh pemerintahan Kolonial.11 Perbanditan merupakan resistensi12 kaum pribumi atas kemiskinan, tekanan pajak, kerja wajib, dan kondisi sosial-ekonomi yang merugikan kaum pribumi. Berdasarakan kesadaran politiknya, perkecuan merupakan bagian dari kasus perbanditan yang tergolong dalam gerakan setengah sadar politik.

Praktek kecu di Surakarta memiliki sejarah tersendiri, sebab fenomena kecu terjadi diperkirakan karena para pelaku mengalami kekurangan pangan. Sehingga, motif perkecuan adalah motif ekonomi. ${ }^{13}$ Fenomena perkecuan masih berlangsung hingga awal abad ke-20. Salah satu wilayah yang sering menjadi sasaran para kecu adalah daerah Colomadu. Sasaran para kecu semula hanya

${ }^{8}$ Eep Saefulloh Fatah, Mencintai Indonesia dengan Amal : Refleksi atas Fase Awal Demokrasi (Jakarta : Republika, 2004), hlm. 39-40.

9 Istilah Neerlandosentris dipakai Sartono Kartodirdjo, Indonesian Historiography (Yogyakarta : Kanisius, 2001), hlm. 29-30. Makna kata Neerlandosentris : pikiran atau perilaku yang menggunakan sudut pandang Belanda, dengan menonjolkan tokoh atau peristiwa yang memihak Belanda.

10 Istilah Indonesiasentris diartikan sebagai pendekatan menggunakan sudut pandang Indonesia yang menempatkan Indonesia sebagai pusat perhatian sekaligus memegang peranan. Lihat Ibnu Qoyim Isma'il, Kiai Penghulu Jawa : Peranannya di Masa Kolonial (Jakarta : Gema Insani Press, 1997), hlm. 23. Menurut Purwanto dan Ali, Indonesiasentris dimaknai sebagai sejarah dengan sudut pandang Indonesia. Jadi dapat dikatakan bahwa Indonesiasentris sebenarnya adalah yang berorientasi pada masyarakat Indonesia dan penggunaan perspektif sejarah Indonesia. Tentang hal ini periksa M Faishal Aminuddin, Globalisasi dan Neoliberalisme: Pengaruh dan Dampaknya bagi Demokratisasi Indonesia (Yogyakarta : Logung Pustaka, 2009), hlm. 285.

11 Suhartono, Bandit-bandit Pedesaan di Jawa : Studi Historis 1850-1942 (Yogyakarta : Aditya Media, 1995), hlm. 130.

${ }^{12}$ Pada hakikatnya resistensi tidak lain adalah manifestasi dari balance power. Kekuatan kolonial yang terlalu besar pada dasarnya tidak dapat diimbangi oleh petani. Dengan kekuatan yang ada, petani mencoba mengimbangi kekuatan pemerintah. Dalam hal perbanditan pedesaan dapat dimasukkan dalam resistensi petani. Periksa ibid., hlm.18 dan 104.

${ }^{13}$ Wasino, op., cit., hlm. 326. 
ditujukan kepada etnis Cina, sebagai salah satu bentuk sentimen rasial kaum pribumi. Namun dalam perkembangannya, sasaran para kecu bukan hanya etnis Cina, melainkan juga orang Eropa, orang kaya asing, serta orang Jawa dari kalangan menengah keatas. ${ }^{14}$ Di Vorstenlanden ${ }^{15}$, fenomena perkecuan merupakan praktek perampokan yang paling banyak mengisi khasanah kriminalitas di daerah Surakarta. ${ }^{16}$ Pada tahun 1915, praktek perkecuan di Surakarta jumlahnya relatif cukup besar yaitu 51 kasus. Jumlah ini dibandingkan dengan tahun 1900-an, rata-rata kurang dari 10 kasus perkecuan. Kasus perkecuan paling tinggi terjadi pada tahun 1919, yaitu mencapai 85 kasus. Angka ini menurun drastis pada tahun 1924, karena hanya terdapat 24 kasus.

Pada tahun tersebut juga bersamaan dengan munculnya organisasi Sarekat Islam yang merekrut banyak massa termasuk kalangan buruh dan petani. Sehingga Sarekat Islam mampu meredam peningkatan perkecuan, dimana sebagian besar pelaku perkecuan dilakukan oleh para petani. Organisasi Sarekat Islam lebih mengarahkan massanya pada pergeseran gerakan reaksi, yakni dari gerakan tradisional ke gerakan modern melalui organisasi. Hal inilah yang memunculkan korelasi antara resistensi petani dan gerakan massa Sarekat Islam. ${ }^{17}$. Maka, fenomena perkecuan merupakan bagian dari praktek "sentimen rasial secara radikal" dari kaum pribumi. Kehadiran Sarekat Islam ditengahtengah keterpurukan kondisi sosial-ekonomi kaum pribumi dapat mengurangi praktek "sentimen rasial secara radikal", seperti fenomena perkecuan bermotifkan ekonomi.

\section{Sarekat Islam sebagai Alat Pencari Identitas Kebangsaan}

Lahirnya Sarekat Islam berdasarkan pada persamaan seluruh umat di tahun 1912, dalam usahanya untuk meningkatkan kesejahteraan disambut rakyat banyak khususnya dari lapisan bawah. Petani dan buruh mendapat kesempatan yang sama untuk bergabung agar nasibnya terbela. Sebenarnya, keduanya saling memperoleh kentungan. Bagi Sarekat Islam yang baru terjun dalam aktivitas ekonomi dan politik, maka kedudukan buruh dan petani memperkuat gerakannya untuk memperjuangkan tujuan kepada pemerintah. ${ }^{18}$ Keanggotaan Sarekat Islam mengalami perkembangan pesat. Kondisi tersebut memberikan gambaran bahwa Sarekat Islam mendapat perhatian dari kaum pribumi, terlebih dari kalangan buruh dan petani. Hal ini tidak terlepas dari karakteristik Sarekat Islam yang beranggotakan masyarakat dari berbagai lapisan. Sarekat Islam diharapkan mampu menjadi tempat penyalur cita-cita atas perbaikan kesejahteraan hidup ditengah-tengah keterpurukan sosial-ekonomi

14 Ibid., hlm. 325.

15 Istilah vorstenlanden digunakan Marwati Djoened Poesponegoro dan Nugroho Notosusanto, Sejarah Nasional Indonesia V (Jakarta : Balai Pustaka, 2008), hlm. 185. Arti kata vorstenlanden : daerah kerajaan.

16 Suhartono, op.,cit, hlm.132.

17 Ibid,. hlm. 146.

18 Ibid, hlm. 124. 
saat itu, serta berjuang merebut kembali hak-hak kaum pribumi yang dirampas oleh Kolonial Belanda.

Kesamaan nasib dan tujuan tersebut "mengikat" kaum pribumi dalam sebuah wadah organisasi, sehingga mendorong lahirnya "kepentingan bersama" yang pantas diperjuangkan dan direbut kembali dari tangan Kolonial Belanda. Rasa kesatuan dan semangat nasionalisme inilah yang menjadikan Sarekat Islam digunakan sebagai alat pencari identitas kebangsaan kaum pribumi di Surakarta, pada masa radikal Indonesia. Kesamaan-kesamaan tersebut mendorong adanya usaha mewujudkan perjuangan atas "kepentingan bersama", bersatu untuk bersama-sama membela hak bumi-putera dari Kolonial Belanda merupakan bagian dari proses pencarian identitas keindonesiaan kaum pribumi.

\section{PENUTUP}

Kebijakan politik dan ekonomi Kolonial Belanda di Surakarta awal abad ke-20 memunculkan kesenjangan sosial yang tinggi. Adanya hak-hak istimewa dari Kolonial Belanda kepada etnis Cina seperti dalam bidang perdagangan, menimbulkan ketimpangan sosial bagi kaum pribumi. Hal ini melatarbelakangi terjadinya sebuah tindakan "sentimen rasial secara radikal" dari kaum pribumi terhadap etnis Cina. Sikap sentimen rasial tersebut tercermin dari meningkatnya fenomena perkecuan di Surakarta. Sentimen rasial ini merupakan salah satu bentuk konflik antara kaum pribumi dengan etnis Cina. Konflik ini ternyata mendorong lahirnya Sarekat Islam. Hadirnya Sarekat Islam ditengah-tengah keterpurukan sosial-ekonomi merupakan bentuk resistensi kaum pribumi dalam menghadapi persaingan dengan etnis Cina, sekaligus sebagai tindakan bertahan menghadapi kebijakan Kolonial Belanda. Dalam perkembangannya, Sarekat Islam mampu merangkul anggota yang sebagian besar berasal dari kalangan petani dan buruh.

Kondisi ini menciptakan sebuah hubungan erat antara kaum pribumi terhadap gerakan massa Sarekat Islam. Sarekat Islam mampu meredam peningkatan perkecuan dengan lebih mengarahkan massanya pada pergeseran gerakan reaksi, yakni dari gerakan tradisional ke gerakan modern melalui organisasi. Ini berarti, Sarekat Islam mampu mengurangi terjadinya "sentimen rasial secara radikal" dari kaum pribumi terhadap etnis Cina. Tidak hanya itu, secara bersamaan Sarekat Islam juga mampu mendorong massanya untuk memperjuangkan "kepentingan bersama" atas dasar kesamaan nasib dan tujuan, yakni memperjuangkan hak-hak rakyat yang telah direbut Kolonial Belanda. Sehingga, rasa persatuan-kesatuan dan semangat nasionalisme inilah yang menjadikan Sarekat Islam digunakan sebagai alat pencari identitas kebangsaan, sekaligus merupakan bagian dari proses pencarian identitas keindonesiaan kaum pribumi di Surakarta, pada masa radikal Indonesia yakni awal abad ke-20. 


\section{REFERENSI}

Benny G Setiono, Tionghoa dalam Pusaran Politik. Jakarta: Transmedia, 2008.

Budi Susanto, Identitas dan Postkolonialitas di Indonesia. Yogyakarta: Kanisius, 2004.

Eep Saefulloh Fatah, Mencintai Indonesia dengan Amal: Refleksi atas Fase Awal Demokrasi. Jakarta: Republika.

Ferdinand Suleeman, dkk penyunting, Bergumul dalam Pengharapan.Jakarta: Gunung Mulia, 2004.

Ibnu Qoyim Isma'il, Kiai Penghulu Jawa: Peranannya di Masa Kolonial.Jakarta: Gema Insani Press, 1997.

Marwati Djoened Poesponegoro dan Nugroho Notosusanto, SejarahNasional Indonesia V. Jakarta: Balai Pustaka, 2008.

M. Faishal Aminuddin, Globalisasi dan Neoliberalisme: Pengaruh dan Dampaknya bagi Demokratisasi Indonesia. Yogyakarta: Logung Pustaka,2009.

Sartono Kartodirdjo, Sejarah Nasional Indonesia IV. Jakarta: Balai Pustaka, 2008.

Sartono Kartodirdjo, Indonesian Historiography. Yogyakarta: Kanisius, 2001.

Sartono Kartodirdjo, Pemberontakan Petani Banten 1888: Kondisi, Jalan Peristiwa, dan Kelanjutannya: Sebuah Studi Kasus Mengenai Gerakan Sosial di Indonesia. Jakarta: Pustaka Jaya, 1984.

Srijanti dkk, Etika Berwarga Negara Edisi II: Pendidikan Kewarganegaraan untuk Perguruan Tinggi. Jakarta: Salemba Empat, 2008.

Suhartono, Bandit-bandit Pedesaan di Jawa: Studi Historis 1850-1942. Yogyakarta: Aditya Media, 1995.

Takashi Shiraishi, Zaman Bergerak: Radikalisme Rakyat di Jawa 1912-1926, penerjemah Hilmar Earid. Jakarta: Pustaka Utama Grafiti, 1997.

Tissa Balasuriya, Teologi Siarah. Jakarta: Gunung Mulia, 2004. 